\title{
Antidumping, A Choice Between Unilateral Duties or Negotiation of a Suspension Agreement: The Aftermath of Techsnabexport, Ltd. v. United States
}

\section{INTRODUCTION}

More than a century has passed since the Sherman Antitrust Act of $1890,{ }^{1}$ the first major body of law regulating foreign trade in the United States, was enacted. A line of statutes has developed to address the problem of foreign merchandise being sold at discriminatory prices, or "dumped," in the United States. ${ }^{2}$ The purpose of these laws is to protect domestic industries from unfair competition. ${ }^{3}$ One of the most - powerful regulations ${ }^{4}$ in international trade is the Antidumping Act of $1921,{ }^{5}$ which is administered by the International Trade Commission (Commission) and the International Trade Administration (ITA), under the authority of the Department of Commerce (Commerce). This statute provides only an administrative remedy and consequently does not afford direct damages to an injured domestic industry. ${ }^{6}$ The incentive for initiating an antidumping investigation results from perceptions that another country's industry is attempting to gain a competitive advantage

1. Sherman Antitrust Act, Ch. 349, 28 Stat. 509 (current version at 15 U.S.C. IS 1-7 (1988)).

2. Michael Huecker, Nichimen America, Inc. v. United States: The Federal Circuit Untangles the Statutory Framework for Review of Antidumping Proceedings, 17 N.C. J. INT'L L. \& COM. REg. 531 (1992) (tracing the development of legislation attempting to prevent price discrimination; including the 1890 Sherman Antitrust Act, the Wilson Tariff Act, the 1916 Revenue Act, the Antidumping Act of 1921, the Tariff Act of 1930, and finally the 1979 Trade Agreements Act containing modern day antidumping law).

3. Peter Ehrenhaft, Remedies Against "Unfair" International Trade Practices, 12 A.L.I.-A.B.A. Course Materials Journal 93, 95 (1987).

4. See Charlene Barshefsky \& Nancy B. Zucker, Amendments to the Antidumping and Countervailing Duty Laws Under The Omnibus Trade and Competitiveness Act of 1988, 13 N.C. J. InT'L L. \& Сom. REg. 251 (1988) [hereinafter Barshefsky \& Zucker].

5. Antidumping Act of 1921 , Ch. 14, 42 Stat. 9 (codified in 19 U.S.C. 1303), repealed by Trade Agreements Act of 1979, Pub. L. No. 96-39, 93 Stat. 144 (codified as amended in Chapter 4 of the Tariff Act, Title IV, 19 U.S.C. 16731677 (1988)).

6. Ehrenhaft, supra note 3, at 96. Compare Trade Agreements Act of 1916, 15 U.S.C. $\$ 72(1988)$, which created a private cause of action similar to antitrust statutes, but is rarely used because the claimant must prove predatory intent. 
in a particular market by cutting prices, or to completely eliminate domestic producers. ${ }^{7}$ Dumping could lead to a foreign producer gaining a monopoly, and potentially controlling United States prices. ${ }^{8}$ Ideally, the purpose of antidumping legislation is to ensure a "level playing field" in international trade, not to compensate an injured industry by awarding monetary damages. ${ }^{9}$

A recent antidumping investigation against producers in the former Soviet Union raised two issues rarely or never before addressed. In Techsnabexport (Tenex), Ltd. $v$. United States, ${ }^{10}$ uranium importers unsuccessfully challenged the legality of an antidumping investigation against twelve former Soviet republics. In a case of first impression, the Court of International Trade addressed the question of whether an investigation may continue after the country against which it was initiated has dissolved. The Commission's decision to continue the investigation against six republics ${ }^{11}$ was upheld twice within four months by the court. Tenex involves a unique fact pattern, and the dissolution of an established nation rarely occurs. However, the case is important because the holdings indicate precedent for other importers or nations who might attempt to prematurely terminate an antidumping proceeding because of a change in government. The modern international trade arena includes an increasing number of new nations or restructured governments eager to create healthy trade relations with economically stable countries such as the United States. Tenex not only demonstrates how the court will apply American antidumping law, but reveals how the negotiation of a suspension agreement can promote a sound trade relationship.

As a background to the Tenex case, the relevant sections of the Antidumping Act will first be discussed. In Part II, the issues raised and the cases relied upon in the Court of International Trade's review of the Tenex investigation and its subsequent holdings will be examined. The significance and consequences of this case will be discussed in Part

7. Huecker, supra note 2, at 531 (citing Charlene Barshefsky \& Richard O. Cunningham, The Prosecution of Antidumping Actions Under the Trade Agreements Act of 1979, 6 N.C. J. Int'L L. \& Com. Reg. 307, 308 (1981)).

8. Barshefsky \& Zucker, supra note 4, at 254.

9. Michael Sandler, Primer on United States Trade Remedies, 19 INT'L Law 761, 763 (1985).

10. Techsnabexport, Ltd. v. United States, 795 F. Supp. 428 (Ct. Int'l Trade 1992)[hereinafter Tenex]. See also later proceeding 802 F.Supp. 469 (Ct. Int'l Trade 1992)[hereinafter Tenex II].

11. The six republics which Commerce initiated final investigation proceedings against are: Kazakhstan, Kyrgyzstan, Russia, Tajikistan, Ukraine, and Uzbekistan. 
III, including the suspension agreements negotiated to prevent imposition of antidumping duties. Part IV concludes that the decision to continue an antidumping proceeding, regardless of whether a country's political boundaries have changed, was correct. However, it will be proposed that the time and cost spent during the investigation process would have been significantly reduced if the United States and Commerce more strongly encouraged negotiation of suspension agreements as an initial step in antidumping proceedings.

\section{A. Antidumping Procedure}

Although the Antidumping Act does not define dumping in detail, it generally proscribes three types: (1) price discrimination, (2) belowcost sales, and (3) "constructed" below-cost sales. ${ }^{12}$ Price discrimination is selling merchandise in a certain market at prices lower than similar merchandise is sold in the home or other foreign markets, without corresponding differences in production or transportation costs. ${ }^{13}$ Belowcost selling occurs when merchandise is sold in the United States at prices lower than in the home market, and possibly lower than the cost of production. ${ }^{14}$ Similarly, when merchandise is sold in the United States at prices lower than it is sold in third countries, the method of dumping is labeled constructed below-cost sales. ${ }^{15}$

An antidumping duty investigation may be initiated either by petition from an "interested party"16 on behalf of a domestic industry

12. Steven F. Benz, Note, Below-Cost Sales and the Buying of Market Share, 42 Stan. L. REv. 695, 710 (1990). Benz indicates three categories of dumping defined by economists as: (1) sporadic discounts to reduce surplus, (2) permanent policy of low cost sales to cover marginal costs, and (3) predatory or intentional dumping to destroy a domestic industry. Of these, (2) and (3) are considered unfair long-term trade practices and are subject to antidumping laws. Id.

13. Id. at 714-15.

14. Id. at 728 .

15. Id. See also Sandler, supra note 9 , at 765.

16. 19 U.S.C. $\$ 1677(9)$. An interested party may be:

(A) a foreign manufacturer, producer, or exporter, or the United States importer, of merchandise which is the subject of an investigation under this subtitle or a trade or business association a majority of the members of which are importers of such merchandise,

(B) the government of a country in which such merchandise is produced or manufactured,

(C) a manufacturer, producer, or wholesaler in the United States of a like product,

(D) a certified union or recognized union or group of workers which is 
or by Commerce sua sponte. ${ }^{17}$ Next, the Commission and the ITA together make a series of determinations in a lengthy and complicated process.

The Commission first makes a preliminary determination of injury or threat of injury to the domestic industry. ${ }^{18}$ At the same time, the ITA makes a preliminary decision of whether there is a reasonable indication that merchandise is "being sold, or is likely to be sold, at less than fair value."19 Within seventy-five days of its preliminary determination, the ITA must make a final determination regarding sales at less than fair value (LTFV). ${ }^{20}$ If the ITA makes an affirmative final LTFV determination, the Commission must make a final injury determination within seventy-five days. ${ }^{21}$

If both the Commission and ITA make an affirmative final determination, the ITA issues an antidumping duty order. ${ }^{22}$ Customs then assesses a duty "equal to the amount by which the foreign market value of the merchandise exceeds the United States price." 23

\section{B. Review of Antidumping Duty Order}

The majority of administrative and judicial reviews take place after a final dumping determination is reached. The Antidumping Act provides for administrative review of antidumping duty orders or suspension

representative of an industry engaged in the manufacture, production or wholesale in the United States of a like product,

(E) a trade or business association a majority of whose members manufacture, produce, or wholesale a like product in the United States,

(F) an association, a majority of whose members is composed of interested parties described in subparagraph $(C),(D)$, or $(E)$ with respect to a like product ....

Id.

17. 19 U.S.C. $\$ 1673 \mathrm{a}(\mathrm{a})$.

18. Id. $1673 \mathrm{~b}(\mathrm{a})$.

19. Id. $\$ 1673 \mathrm{~b}(\mathrm{~b})$.

20. Id. $\$ 1673 \mathrm{~d}(\mathrm{a})$. This final determination shall be made even if the preliminary less than fair value (LTFV) determination was negative. As long as the preliminary determination of injury is affirmative, the investigation will continue to its final stages. Id.

21. Id. $1673 \mathrm{~d}(\mathrm{~b})(3)$. An antidumping investigation, without extensions for extremely complicated cases, can take up to 310 days (or more than 10 months).

22. Id. $\ 1673 \mathrm{~d}(\mathrm{c})$.

23. Id. $1673 \mathrm{e}$. The basis for antidumping duty comes from the ITA's calculation of foreign market value during the investigation. Id. See also $\$ 1673 \mathrm{f}$, directing how to treat the difference between the estimated duty deposit and the actual duty assessment. 
agreements at the request of an interested party, ${ }^{24}$ but only where sufficiently changed circumstances are shown. ${ }^{25}$ In addition, the Tariff Act of 1930 supplies rules for protest and judicial review immediately after any determination by the Commission or the ITA.$^{26}$ Within thirty

24. Id. $\$ 1675(\mathrm{a})(1)$. To prevent unnecessary costs, the 1984 amendments to the Trade and Tariff Act added the stipulation that administrative review will not occur without a formal request from an interested party. Id. (Pub. L. No. 98-573, $\$$ 611,98 Stat. 2948, 3031).

25. Id. 1675(b)(1). Absent good cause, review of preliminary determinations under $1673 \mathrm{~b}$ and suspension agreements under $\$ 1673 \mathrm{c}$ cannot be reviewed "less than 24 months after the date of publication of notice of that determination or suspension." Id. $\$ 1675(\mathrm{~b})(2)$. All other determinations may be reviewed at least twelve months after their publication. Id. $\$ 1675(\mathrm{a})$.

26. Tariff Act of 1930,19 U.S.C. $\$ 1516$ a (1988). The statute allows judicial review in antidumping duty proceedings under the following circumstances:

(B) Reviewable determinations

The determinations which may be contested under subparagraph $A$ are as follows:

(i) Final affirmative determinations by the administering authority [ITA] and by the Commission under section $1671 \mathrm{~d}$ or $1673 \mathrm{~d}$ of this title, including any negative part of such a determination (other than a part referred to in clause (ii)).

(ii) A final negative determination by the administering authority or the Commission under $1671 \mathrm{~d}$ or $1673 \mathrm{~d}$ of this title, including, at the option of the appellant, any part of a final affirmative determination which specifically excludes any company or product.

(iii) A final determination, other than a determination reviewable under paragraph (1), by the administering authority or the Commission under section 1675 or this title.

(iv) A determination by the administering authority, under section 1671c or $1673 \mathrm{c}$ of this title, to suspend an antidumping duty or countervailing duty investigation, including any final determination resulting from a continued investigation which changes the size of the dumping margin or net subsidy calculated, or the reasoning underlying such calculations, at the time the suspension agreement was concluded.

(v) An injurious effect determination by the Commission under section $1671 \mathrm{c}(\mathrm{h})$ or $1673 \mathrm{c}(\mathrm{h})$ of this title.

(vi) A determination by the administering authority as to whether a particular type of merchandise is within the class or kind of merchandise described in an existing finding of dumping or antidumping or countervailing duty order.

(3) Exception-Notwithstanding the limitation imposed by paragraph (2)(A)(i)(II) of this subsection, a final affirmative determination by the administering authority under section $1671 \mathrm{~d}$ or $1673 \mathrm{~d}$ of this title may be contested by commencing an action, in accordance with the provisions of paragraph $(2)(A)$, within thirty days after the date of publication in the 
days of publication of certain determinations, any party to the proceeding may request judicial review by the Court of International Trade. ${ }^{27}$ The court "shall hold unlawful any [administrative] determination ... found ... to be arbitrary, capricious, an abuse of discretion, or otherwise not in accordance with law, or . . . unsupported by substantial evidence on the record . . . ."28 The circumstances giving cause-for review are final affirmative determinations, final negative determinations, determinations upon administrative review, determinations to terminate or to suspend an investigation, an injurious effect determination, or a determination of whether particular merchandise is within the class to be investigated. ${ }^{29}$

Because the Antidumping Act only allows judicial review under the above enumerated circumstances, Congress found it necessary to add a general grant of jurisdiction to provide for review of unique situations. Through the Customs Court Act of 1980, Congress conferred exclusive jurisdiction to the Court of International Trade for antidumping actions. ${ }^{30}$ In addition to the enumerated circumstances of the Antidumping Act, residual jurisdiction was granted for controversies concerning "tariffs, duties, fees, or other taxes on the importation of merchandise" where jurisdiction under another subsection of the Customs Court Act is unavailable. ${ }^{31}$ The threshold issue in Tenex was whether the legality of an antidumping proceeding can be reviewed, prior to any final agency determination, pursuant to the residual jurisdiction provision of the Customs Court Act.

Federal Register of a final negative determination by the Commission under section $1671 \mathrm{~d}$ or $1673 \mathrm{~d}$ of this title.

Id. at $\$ 1516 \mathrm{a}(\mathrm{a})(2)(\mathrm{B})$.

27. Id. $\$ 1516 \mathrm{a}(\mathrm{a})(1)$.

28. Id. $\$ 1516 \mathrm{a}(\mathrm{b})(1)$.

29. Id. $1516 \mathrm{a}(\mathrm{a})(2)(\mathrm{B})$.

30. Customs Court Act of 1980, Pub. L. No. 96-417, 94 Stat. 1747 (codified as amended in scattered sections of 28 U.S.C.). The Customs Court was renamed the Court of International Trade to reflect "more accurately . . . the court's clarified and expanded jurisdiction and its new judicial functions relating to international trade." H.R. REP. No. 1235, 96th Cong., 2d Sess. 18 (1980), reprinted in 1980 U.S.C.C.A.N. 3729 .

31. 28 U.S.C. $\$ 1581$ (i)(2) (1988). Subsection (c) grants exclusive jurisdiction to the Court of International Trade to hear "any civil action commenced under section 516 A of the Tariff Act of 1930 [19 U.S.C. $\$ 1516$ a]." Subsection (i)(4) also provides an equitable remedy of residual jurisdiction, but states that it "shall not confer jurisdiction over an antidumping ... duty determination which is reviewable ... under section 516A(a) of the Tariff Act of 1930 [19 U.S.C. $\$ 1516 \mathrm{a}(\mathrm{a})$ ]." Id. 


\section{Provision for Suspension of Investigation}

The Antidumping Act provides three alternative methods to suspend antidumping proceedings. An investigation may be terminated by (1) withdrawal of petition, (2) an agreement to completely eliminate either exports or sales at less than fair value, or (3) an agreement to eliminate the injurious effect. ${ }^{32}$ Commerce must be satisfied that ending the proceeding is in the public interest and can be practically monitored before accepting an agreement. ${ }^{33}$ The Tenex case was eventually concluded by a suspension agreement negotiated between Russia and the United States. The agreement was signed on the eve of the scheduled date for imposition of duties on incoming uranium.

If Commerce receives a request from an interested party to continue the investigation within twenty days after notice of suspension, it can only do so under certain circumstances. ${ }^{34}$ The investigation will be resumed if the agreement no longer meets the statutory requirements ${ }^{35}$ or the exporters violate the agreement. ${ }^{36}$ The Antidumping Act also provides for review of the suspension agreement by petition from an interested party within twenty days after the suspension notice. ${ }^{37}$

II. Statement of the Gase: Techsnabexport, Ltd. v. United STATES

\section{A. Factual Background}

On November 8, 1991, pursuant to American antidumping laws, the Ad Hoc Committee of Domestic Uranium Producers and the Oil,

32. 19 U.S.C. $\$ 1673 \mathrm{c}$.

33. Id. $\$ 1673 \mathrm{c}(\mathrm{a}),(\mathrm{b})$, and (c).

34. Id. $\$ 1673 \mathrm{c}(\mathrm{f})$ and $(\mathrm{g})$. The relevant portions state:

(3) where investigation is continued. If, pursuant to subsection (g) of this section, the administering authority and the Commission continue an investigation in which an agreement has been accepted under subsection (b) or (c) of this section, then ...

(B) if the final determinations by the administering authority and the Commission under such section are affirmative, the agreement shall remain in force, but the administering authority shall not issue an antidumping duty order in the case so long as ...

(ii) the agreement continues to meet the requirements of subsections (b) and (d), or (c) and (d) of this section, and

(iii) the parties to the agreement carry out their obligations under the agreement in accordance with its terms.

Id.

35. See id. $1673 c(b),(c)$, and (d).

36. Id. $1673 \mathrm{c}(\mathrm{i})$.

37. Id. $1673 \mathrm{c}(\mathrm{h})$. 
Chemical and Atomic Workers International Union filed a petition requesting initiation of an investigation against uranium exporters from the Union of Soviet Socialist Republics (U.S.S.R.). ${ }^{38}$ The domestic industry (industry) alleged that imports during 1989-91 of natural and enriched uranium "present a real threat of material injury to the United States uranium industry" and that "actual injury is imminent.",39 According to the industry, foreign uranium imports adversely affect domestic prices both directly by price-cutting, and indirectly by increasing the volume of foreign uranium in the marketplace. ${ }^{40}$ The imported products to be investigated include uranium ores and concentrates; natural and enriched uranium metal and uranium compounds; and alloys, dispersions, or ceramic products and mixtures containing natural or enriched uranium. ${ }^{41}$ In light of the U.S.S.R.'s political turmoil at the time, ${ }^{42}$ the industry specifically named each individual republic to ensure relief in case any of them withdrew. ${ }^{43}$ The Commission made its preliminary affirmative injury determination on December 23, 1991.44

After months of Parliamentary debate in Moscow, dissolution of the Soviet nation was formally announced on December 25, 1991.45 On January 10, 1992, Tenex, the largest uranium exporter from the U.S.S.R., and Nuexco Trading Corporation, the sole American im-

38. Uranium from the Union of Soviet Socialist Republics, 56 Fed. Reg. 63,711 (Dep't Comm. 1991) (initiation of antidumping duty investigation) [hereinafter Initiation]. The Antidumping Act allows imposition of antidumping duties if a "class or kind of foreign merchandise is being, or is likely to be, sold . . . at less than its fair value, and ... an industry in the United States is materially injured, or is threatened with material injury." 19 U.S.C. $\$ 1673$.

39. Michael Knapik and Wilson Dizard III, Producers, Union File Antidumping Case Against Imports of Soviet Uranium, 16 NuclearFuel No. 24, at 1 (November 25, 1991).

40. Id.

41. Initiation, supra note 38 .

42. See Andranik Migranyan, Can Yeltsin's Russia Survive?, 12 Moscow News WeEkly No. 40 (October 2, 1991). The author states: "The instant collapse of the U.S.S.R. has suprised not only the advocates of a renovated empire, but also its most ruthless destroyers. It was an explosion rather than a new bout of centrifugal tendencies." Id. See also L.T., Last Days of the U.S.S.R. Supreme Soviet, 15 Moscow News WeEKLY No. 51 (December 18, 1991).

43. Tenex, 795 F. Supp. 431 n.4.

44. Uranium from the U.S.S.R., 57 Fed. Reg. 68 (Dep't Comm. 1992) (affirmative preliminary injury determination).

45. See The Soviet Parliament Adopts a Resolution on the End of the U.S.S.R., Agence Europe, December 25, 1991, available in LEXIS, Newspaper Library, International File. 
porter, requested Commerce to terminate the investigation since the country named in the petition had ceased to exist. ${ }^{46}$ Commerce announced on March 24, 1992, that it intended to continue the investigation and had issued questionnaires to the twelve newly independent republics. ${ }^{47}$

The deadline for a preliminary dumping determination was extended until May 18, as it was an "extraordinarily complicated" investigation. ${ }^{48}$ Commerce stated that although Tenex was attempting to cooperate, Commerce found it difficult to communicate with the new republics. ${ }^{49}$ The "situation where the country identified in the petition has dissolved" was also cited as an issue novel enough to warrant extension of the investigation. ${ }^{50}$

Two republics, Ukraine and Tajikistan, filed suit on April 9, 1992, requesting that the Court of International Trade order the Commission to cease its antidumping investigation. ${ }^{51}$ Tenex subsequently made the same request for injunctive relief and the actions were consolidated. The republics and Tenex (collectively referred to as Tenex) named three forms of irreparable injury that would result if the investigation was continued, including denial of right to due process of law, interference with credibility as sovereign nations, and interference with ability to function effectively in the international trading community. ${ }^{52}$

\section{B. In the Court of International Trade: May 21, 1992}

The first proceeding in the Court of International Trade resolved two issues. The first issue addressed was whether the court had jurisdiction to hear a challenge to the legality of an antidumping investigation before any final determinations were made by the Commission. ${ }^{53}$ The

46. Tenex, 795 F. Supp. at 431.

47. Id.

48. Uranium from the Former Union of Soviet Socialist Republics (USSR), 57 Fed. Reg. 11,064-02 (Dep't Comm. 1992) (postponement of preliminary antidumping duty determination)[hereinafter Postponement].

49. Id. Under subsection (c) of 19 U.S.C. $\$ 1673 \mathrm{~b}$, the investigation may be extended in "extraordinarily complicated cases" including (1) large number and complexity of transactions, (2) novelty of issues, or (3) number of firms to be investigated. The notice of postponement and specific reasons must be published in the Federal Register. 19 U.S.C. $\$ 1673 b(c)$.

50. Id.

51. Tenex II, 802 F. Supp. at 470.

52. Michael Knapik, Two CIS Countries File Suit to Block Antidumping Uranium Case, 17 NuclearFuel No. 8, at Extra (April 13, 1992).

53. Tenex, 795 F. Supp. at 432-33. 
second issue was whether a decision by the Commission to continue an antidumping investigation after the country named in the petition has ceased to exist violates due process and warrants injunctive relief. ${ }^{54}$

\section{Residual Jurisdiction}

Tenex asserted that the court had residual jurisdiction under section 1581(i) of the Customs Court Act. The defendant United States (government) asserted that Tenex would have an adequate remedy by protesting the continued investigation after a final affirmative duty determination was issued, granted in section 1581(c).$^{55}$ Tenex argued that such a remedy would be manifestly inadequate because "mere continuation of the investigation will cause irreparable harm . . .", 56

Section 1581 of the Customs Court Act grants exclusive subject matter jurisdiction to the Court of International Trade to review proceedings arising under the Tariff Act of 1930. ${ }^{57}$ Subsections (a) through (h) narrowly define areas in which the court has jurisdiction. ${ }^{58}$ In addition, Congress provided residual jurisdiction in subsection (i) for controversies that do not fit under subsections (a)-(h) ${ }^{59}$ Both the Court of International Trade and the federal circuit have read the additional provision narrowly, only allowing its use in exceptional circumstances. ${ }^{60}$

The court in Tenex held that residual jurisdiction may be invoked where "another subsection of [section] 1581 is unavailable or the remedy provided by the other subsection is "manifestly inadequate'." 61 The court relied on several cases that applied residual jurisdiction in antidumping or countervailing duty cases, including Asociacion Colombiana de Exportadores de Flores (Asocoflores) v. United States ${ }^{62}$ and Carnation En-

54. Id. at $430-31$.

55. Id. at $432-33$.

56. Id. at 433 .

57. 28 U.S.C. $\$ 1581$.

58. Id. $\ 1581(\mathrm{a})-(\mathrm{h})$.

59. Id. $\$ 1581(\mathrm{i})$.

60. Honorable Gregory W. Carman, The Jurisdiction of the United States Court of International Trade: A Dilemma for Potential Litigants, 22 Sterson L. Rev. 157, 162 (1992). Without $\$ 1581(\mathrm{i})$ residual jurisdiction, litigants would have to "slide exactly into a glove of eight jurisdictional fingers, listed at 28 U.S.C. $\$ 1581(\mathrm{a})-(\mathrm{h})$." Id.

61. Tenex, 795 F. Supp. at 433 (citing National Corn Growers Ass'n v. Baker, 840 F.2d 1547, 1557 (Fed. Cir. 1988); Miller \& Co. v. United States, 824 F.2d 961,963 (Fed. Cir. 1987), cert. denied, 484 U.S. 1041 (1988) (holding that plaintiff who failed to participate in administrative proceedings lacked standing to bring 1581(i) action and remedy under 1581(c) was not manifestly inadequate)).

62. Asociacion Colombiana Exportadores Flores (Asocoflores) v. United States, 717 F. Supp. 847 (Ct. Int'l Trade 1989), aff'd, 903 F.2d 1555 (Fed. Cir. 1990). 
terprises $v$. United States Dep't of Commerce. ${ }^{63}$ The government argued that Tenex was similar to Macmillan Bloedel Ltd. v. United States, ${ }^{64}$ which was a challenge for failure to exclude a party. The court disagreed and distinguished the case from Tenex, stating that Macmillan Bloedel was not as unique and therefore did not compel interim review. ${ }^{65}$ The controversy and confusion among parties and the courts regarding jurisdiction in actions under the Tariff $\mathrm{Act}^{66}$ warrants close examination of the cases cited in Tenex.

In Asocoflores, plaintiffs petitioned for an injunction to prevent the defendant (ITA) from conducting a review of certain producers or exporters of fresh cut flowers, because the Floral Trade Council failed to state specific reasons for the review when requesting it. The ITA argued that residual jurisdiction "should not be utilized to circumvent the exclusive methods of judicial review . . . set forth in 19 U.S.C. [section] 1516a." 67 The ITA also relied upon legislative history, in which Congress explicitly stated that section 1581(i) "was not intended to create new causes of action." 68 The court agreed with these assertions, but found it necessary to examine "whether [section 1581(c)] provides an adequate avenue for relief ...." 69 Because the action was not protesting a preliminary decision or procedural matters by the ITA, the court reasoned that judicial review after a final countervailing duty determination would be unavailable. ${ }^{70}$ Instead, the legality of a "massive review of an entire industry" was being challenged, and the court found such an issue to fit the "extraordinary situation" criterion under section 1581(i). ${ }^{71}$ The court held that it could exercise jurisdiction because "[i]n the absence of specific legislative guidance to the contrary, the court relies on the general presumption in favor of reviewability." 72

Carnation involved Indian exporters of iron construction castings who, before any final determination, attempted to challenge the right

63. Carnation Enter. Pvt. Ltd. v. United States Dep't Commerce, 719 F. Supp. 1084 (Ct. Int'l Trade 1989). 1992).

64. Macmillan Bloedel, Ltd. v. United States, 1992 WL 107336 (Ct. Int'l Trade

65. Tenex, 795 F. Supp. at 433-34

66. Carman, supra note 60 , at 160 .

67. Asocoflores, $717 \mathrm{~F}$. Supp. at 849 . See supra note 26 and accompanying text for enumerated methods of judicial review.

68. Id. (quoting H.R. REP. No. 1235, supra note 30).

69. Id. at 850 .

70. Id.

71. Id. at n.4.

72. Id. at 851 . 
of Commerce to conduct administrative reviews of a dumping order. Commerce argued that adequate judicial review was provided by section $1516 \mathrm{a}$ of the Antidumping Act, ${ }^{73}$ and the exporters were merely "attempting to circumvent the statutory scheme for judicial review after completion of an administrative review." 74 Further, Commerce argued that the exporters lacked standing as "adversely affected" parties and could not file a claim until the agency action is final. ${ }^{75}$ The court noted that the party propounding section 1581(i) jurisdiction "has the burden to show how [another] remedy would be manifestly inadequate." 76

One case cited by Commerce as controlling, Koyo Seiko v. United States, ${ }^{77}$ was distinguished by the Carnation court as involving procedural issues in the administrative process. In contrast, Carnation involved the legality of administrative proceedings. The court agreed that the remedy under 1581(c) would be manifestly inadequate for two reasons. First, if the exporters decline to participate in what they feel are illegal administrative reviews, but a court finds the reviews valid, the exporters then lack standing as participants and would not be able to compel judicial review. ${ }^{78}$ Second, if dumping margins are not found from the review, the exporters will not be "aggrieved parties" and again cannot compel judicial review under 1581(c) jurisdiction. ${ }^{79}$

Secondary support for invoking section 1581(i) jurisdiction in Carnation was found in legislative history. The House Judiciary Committee report stated: "subsection (i) . . . makes it clear that the court is not prohibited from entertaining a civil action relating to an antidumping ... proceeding," as long as the issue does not relate to reviewable procedures specified in section $1516 a^{80}$ In consideration of the statutory language, case precedent, legislative history, and the "general presumption in favor of judicial review," jurisdiction under section 1581(i) was proper. $^{82}$

73. 19 U.S.C. $\$ 1516 \mathrm{a}$.

74. Carnation, 719 F. Supp. at 1087 .

75. Id. at 1088 .

76. Id. at 1089 (citing Miller $\&$ Co., 824 F.2d at 963, and American Air Parcel Forwarding v. United States, 718 F.2d 1546, 1550-51 (Fed. Civ. 1983), cert. denied, 466 U.S. 937 (1984)). The court distinguishes the plaintiff in Miller $\mathbb{G}$ Co., who did not participate in Commerce proceedings (thus deciding the issue on standing), from the plaintiff in Camation who did participate. Id.

77. Koyo Seiko Co. v. United States, 715 F. Supp. 1097 (Ct. Int'l Trade 1989).

78. Carnation, 719 F. Supp. at 1090.

79. Id.

80. Id. (quoting H.R. REP. No. 1235, supra note 30 ).

81. Id. at 1091 .

82. Id. 
In contrast to the two previous cases, the court in Macmillan Bloedel held that it lacked jurisdiction to review a pending countervailing duty investigation because plaintiff (Macmillan) would have a "meaningful opportunity after the final determination to challenge" the denial of exclusion. ${ }^{83}$ Macmillan sought a writ of mandamus ordering Commerce to investigate whether Macmillan should be excluded from a countervailing duty order on softwood lumber products from Canada. The court recognized certain circumstances in which residual jurisdiction under 1581(i) has been appropriate, such as Nissan Motor Corp. v. United States. ${ }^{84}$

In Nissan, Japanese plaintiffs (exporters) who manufactured tapered roller bearings and components sought to prevent the ITA from conducting administrative reviews after Commerce had tentatively decided to revoke their antidumping finding on products exported by plaintiffs. The exporters argued that the ITA had "failed to abide by its own regulations and time limits." 85 The court held that the exporters' action fell within 1581(i) jurisdiction because it was one "which cannot be contested via [section] 1516a." ${ }_{86}$

The Macmillan Bloedel court noted that the cases allowing residual jurisdiction all "would have been denied relief if required to wait for the final determinations." 87 Nissan and similarly cited cases $^{88}$ were distinguished from Macmillan Bloedel on the basis that Macmillan would have a "meaningful opportunity" to seek judicial review after the Commission's final determination. ${ }^{89}$ The reason stated for drawing such a narrow distinction was that, although Congress did not intend to completely preclude interim judicial review in antidumping and countervailing duty cases, the jurisdiction granted under 1581(i) "is not broad." 90

82. Id.

83. Macmillan Bloedel, 1992 WL 107336 at *2. Accord Associacao Industriais Cordoaria Redes v. United States, 828 F. Supp. 978 (Ct. Int'l Trade 1993). 1986).

84. Nissan Motor Corp. v. United States, 651 F. Supp. 1450 (Ct. Int'l Trade

85. Id. at 1453 .

86. Id.

87. Macmillan Bloedel, 1992 WL 107336 at 1 .

88. The court also cited Nakajima All Co. v. United States, 691 F. Supp. 358 (Ct. Int'l Trade 1988); Carnation, 719 F. Supp. 1084; and Asocoflores, 717 F. Supp. 847.

89. Macmillan Bloedel, 1992 WL 107336 at *2.

90. Id. 
Of the above discussed cases, no factual situation or challenge involved is completely on point with the facts or challenge of Tenex. However, the Court of International Trade seems to be more willing to invoke residual jurisdiction when the legality, instead of a procedural aspect, of the administrative proceeding is questioned. Therefore, Tenex found the challenge to the validity of continuing an antidumping investigation after the Soviet Union has ceased to exist sufficient to invoke residual jurisdiction. In addition, the court concluded that "there is no guarantee that an adverse appealable decision will result" from the antidumping investigation. ${ }^{91}$ Based on these two factors, the court held that review under section 1581 (c) would be manifestly inadequate and thus exercised jurisdiction under 1581(i). ${ }^{92}$

\section{Legality of Antidumping Proceedings}

The substantive issue of whether preliminary relief can be granted to prevent the continuation of an allegedly invalid antidumping investigation was next discussed by the court. A balancing test of four factors was deemed necessary, including (1) the likelihood of success on the merits, (2) the threat of immediate irreparable harm if relief is denied, (3) the balance of hardships, and (4) the public interest..$^{93}$

The first factor of success on the merits was not discussed in detail. In fact, the court stated that it is "inappropriate to resolve [the issues] ... according to a likelihood of success on the merits standard." "94 The fourth factor of public interest also did not receive a detailed examination, except the controversy was found "extremely complicated and of great importance to all of the parties." 95 The court hinted that the public interest would favor completing the investigation before deciding upon its validity. ${ }^{96}$ But what the court did not discuss was how an issue important to the parties would also be important to the public. The brevity of the discussion concerning factors one and four left the

91. Tenex, 795 F. Supp. at 434.

92. Id.

93. Id. at 435 .

94. Id. at 437. Because the antidumping investigation was not complete at the time, and therefore not all the necessary information had been gathered, the court seemed unwilling to predict whether the exporters would succeed at a review after final administrative determinations were published.

95. Id.

96. The court stated that "it is inappropriate to resolve them (the issues of statutory interpretation) in a hurried manner." Id. 
remaining factors to weigh heaviest in the court's determination of relief.

Factor two, threat of immediate irreparable harm, was given the most in-depth discussion by the court. Tenex argued that their procedural due process rights were violated, which has been considered sufficient irreparable harm in prior cases to command immediate relief. ${ }^{97}$ A two-part test was applied: 1) did a protected interest exist, and 2) what is necessary to protect the interest if it exists? ${ }^{98}$

For a foreign entity to have a protected interest under the U. S. Constitution, the interest must be one worthy of protection, such as a property interest, but more than a "unilateral expectation." 99 Tenex claimed its property interest is in "avoiding damaged business relationships, lost sales, and arbitrary antidumping duties." ${ }^{100}$ The republics claimed that as interested parties, their interest is found in sections $1677(9)(A)$ and (B) of the Antidumping Act as "access to the United States market." ${ }^{101}$ The court referred to Perry $v$. Sinderman, ${ }^{102}$ which held that "mere subjective expectation of a future business transaction does not rise to the level of an interest worthy of constitutional protection." 103 Consequently, potentially damaged business interest and lost sales were not found to be interests worthy of due process protection in Tenex. Although some courts have held that due process rights stem from import statutes, ${ }^{104}$ this court rejected the argument that the republics have an interest in access to the United States market under

97. Id. (citing Bowman v. Township of Pennsauken, 709 F. Supp. 1329 (D.N.J. 1989) (equal protection and due process violations establish irreparable harm), and Cate v. Oldham, 707 F.2d 1176 (11th Cir. 1983) (violation of First Amendment rights constitutes irreparable injury)).

98. Id. at 435 .

99. Id. (citing American Ass'n of Exporters and Importers-Textile and Apparel Group v. United States, 751 F.2d 1239, 1250 (Fed. Cir. 1985)[hereinafter American $A s s^{\prime} n$ ] (trade association representing domestic importers had no right to challenge on due process grounds because no legitimate claim of entitlement was made and no international agreement gave a proprietary interest)). See also Board of Regents v. Roth, 408 U.S. 564, 571 (1972).

100. Id. (quoting company plaintiff's brief at 51-52).

101. Id. (citing sovereign plaintiffs' brief at 48 ).

102. Perry v. Sinderman, 408 U.S. 593, 603 (1972).

103. Id.

104. See Koyo Seiko, 796 F. Supp. at 523-24 (Commerce's excessive delay in completing final determination implicitly violated due process rights) and Lois Jeans \& Jackets v. United States, 566 F. Supp. 1523, 1527-28 (Ct. Int'l Trade 1983) (lack of notice and opportunity to comment prejudicial enough to violate due process). 
the "interested party" provision of the Antidumping Act. ${ }^{105}$ The court did not expressly distinguish the cases finding due process rights from Tenex, but implied that because those cases gave no detailed explanation of the property interest involved; they do not compel a finding of due process violation in all situations. ${ }^{106}$

Tenex also failed to prove the existence of harm from an alleged due process violation. ${ }^{107}$ Due process includes the elements of notice and the opportunity to be heard. ${ }^{108}$ Both constructive and actual notice of the antidumping investigation was given to all parties under investigation. ${ }^{109}$ Also, because Commerce has delayed the deadline for preliminary determinations to give the republics more time to respond to questionnaires, ample opportunity was given to be heard and participate in the antidumping proceedings. ${ }^{110}$ The court found both elements were offered to Tenex and concluded that the necessary constitutional standards were met. ${ }^{111}$ Because no worthy property interest existed and adequate process was provided, the court found insufficient proof of immediate irreparable injury. ${ }^{112}$

The third factor in determining whether preliminary relief should be granted is a balance of hardships on the parties involved. The court stated that it was "impossible to determine . . . which is suffering the greater harm" at this point in the antidumping proceedings. ${ }^{113}$ Because Tenex had the burden to prove hardship and insufficient evidence was presented, the court presumed the hardships to balance. ${ }^{114}$

After a four-factor balancing test was announced, the court in reality only weighed two out of the four factors. Although it is not clear from the opinion, the reason might have been that the parties had insufficient information to support their arguments because the antidumping proceeding was not complete. The court was perhaps unwilling to make an uninformed ruling at this stage. Preliminary relief was denied because both imminent irreparable harm and demonstrable

105. Tenex, 795 F. Supp. at 436.

106. Id.

107. Id.

108. Id. (citing Barnhart v. United States Treasury Dep't, 588 F. Supp. 1432, 1438 (Ct. Int'l Trade 1984)).

109. Id. at 436 n.13.

110. Id. at 437 .

111. Id. at 436 .

112. Id. at 437 .

113. Id.

114. Id. 
hardship was lacking, therefore the "four-factor" balance fell in the government's favor.

C. Later Proceedings In the Court of International Trade: September 25, 1992

Four months later, four of the six investigated republics again challenged Commerce's decision to continue the uranium antidumping proceedings. ${ }^{115}$ The republics included Kyrgyzstan, Russia, Tajikistan, and the Ukraine. Tenex, the export company, also joined the challenge in the Court of International Trade. In the time between the two actions, the Commission issued a preliminary determination ${ }^{116}$ finding sales at less than fair value in six of the twelve original republics. ${ }^{117}$ The Commission issued notice of the initiation of final antidumping investigation against the six republics on June 17, 1992. ${ }^{118}$ Despite the action filed in the Court of International Trade, the Commission announced its intention to continue the investigation on September 10, 1992. ${ }^{119}$

The court first briefly discussed the question of residual jurisdiction. Although jurisdiction may be raised at any point in the proceedings, and Commerce presented new arguments, the court found those arguments not new enough to "compel the court to reexamine its previous analysis." 120 The sole issue addressed in the second proceeding was whether an antidumping duty investigation may be continued against newly-independent republics after the country named in the original proceeding has dissolved. ${ }^{121}$

The language of the Antidumping Act does not expressly provide an answer to the issue involved in this action. Both Tenex and Commerce based their arguments on the overall structure of the Antidumping Act and "tangentially related provisions of the statute." ${ }_{122}$ Tenex fo-

115. Tenex $I I, 802$ F. Supp. 469.

116. Uranium from Kazakhstan, Kyrgyzstan, Russia, Tajikistan, Ukraine, and Uzbekistan, 57 Fed. Reg. 23,380 (Dep't Comm. 1992) (preliminary determinations of sales at less than fair value).

117. The countries excluded from the preliminary affirmative less than fair value determination were Armenia, Azerbaijan, Byelarus, Georgia, Moldova, and Turkmenistan. Id.

118. Uranium from Kazakhstan, Kyrgyzstan, Russia, Tajikistan, Ukraine, and Uzbekistan, 57 Fed. Reg. 27,065 (Dep't Comm. 1992) (institution of final antidumping investigations).

119. Tenex $I I, 802$ F. Supp. at 471 .

120. Id.

121. Id.

122. Id. 
cused its argument on the use of the word "country" in the statute. ${ }^{123}$ Its rationale was that investigations and duty orders relate to exports from a particular country, so when an investigated country ceases to exist, a new antidumping proceeding must be initiated against each republic evolving from the dissolution. ${ }^{124}$

In essence, Tenex asserted that Commerce's failure to give notice of a new proceeding violated the statute. A secondary argument was that antidumping duties are calculated based on future conduct. ${ }^{125}$ Because the new republics are now market economies instead of statecontrolled economies, past behavior cannot be used to predict future trade practices. ${ }^{126}$

Commerce argued that the statutory focus is on "merchandise", not countries. ${ }^{127}$ Although political boundaries had changed, the merchandise, uranium, was being produced by the same companies in the same locations. ${ }^{128}$ Also, if the antidumping investigation were discontinued, an "impermissible gap" in statutory coverage would be created between the ongoing and new proceedings. ${ }^{129}$ An antidumping investigation can take up to ten months or more before a final negative determination is made and duties are assessed. ${ }^{130}$ Therefore, the republics could potentially continue to dump uranium at less than fair value without statutory repercussions during the gap between the two investigations.

When reviewing an agency determination, the court is compelled to give great deference to administrative decisions, because the agency is presumed to have greater expertise concerning matters that it regulates. ${ }^{131}$ The general statutory construction rule in administrative proceedings was stated in Cheuron U.S.A. v. Natural Resources Defense Council, Inc. ${ }^{132}$ In order to invalidate an agency determination, the court must find the statutory interpretation by the agency contrary to express Congressional intent. ${ }^{133}$ Absent Congressional intent, the construction

123. Id. at 472 .

124. Id.

125. Id.

126. Id.

127. Id. at 471 .

128. Id.

129. Id.

130. See supra, note 21 and accompanying text.

131. Chevron, U.S.A., Inc. v. Natural Resources Defense Council, Inc., 467 U.S. 837,844 (1984).

132. Id.

133. Id. at 843 . 
will be rejected only when it is unreasonable. ${ }^{134}$ The Chevron court also noted that even though two or more interpretations may be reasonable, the court cannot impose its own construction over the agency's reasonable construction. ${ }^{135}$

In Tenex, the court found the statutory intent to lie "somewhere between the arguments of the opposing litigants." 136 Section 1673 of the Antidumping Act allows antidumping duties if a "class or kind of foreign merchandise is being, or is likely to be, sold in the United States at less than its fair value." 137 Even though this statutory language supports the government's argument, the statute also indicates that investigations as well as duty orders should focus on merchandise from a particular country, which assists Tenex's argument. What the statute does not expressly require is that the same country exist at the beginning and end of an antidumping investigation. ${ }^{138}$ The court stated that it should not "concern itself with the new economic policies of respondent countries" when reviewing the legality of an ongoing proceeding because such an issue can be properly addressed at the first annual administrative review. ${ }^{139}$ The court stated that "the merchandise did not evaporate upon dissolution of the Soviet Union."140 Because dissolution of a country rarely happens, Congress was reluctant to expressly provide for such situations in the Antidumping Act. ${ }^{141}$ In its antidumping duty determination, Commerce inferred from the overall purpose of the Act that successor countries must bear the antidumping duties calculated from import prices of their predecessor. ${ }^{142}$ Pursuant to the Chevron rule, the court upheld Commerce's statutory construction as reasonable. ${ }^{143}$

In support of the its conclusion that dissolution of a country does not compel termination of an antidumping investigation, the court relied on the Commission's preliminary determination to continue in a recent case involving similar issues. ${ }^{144}$ In Ferrosilicon from Argentina, the Com-

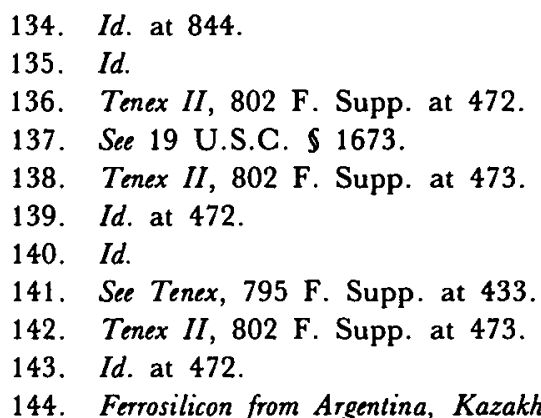
Ukraine and Venezuela, USITC Pub. 2535, Inv. Nos. TA-23, 731-TA-565-570 (Dep't Comm. 1992). 
mission reasoned that to discontinue an investigation merely because the country has dissolved would prevent a domestic industry from being protected under the Antidumping Act, because unfairly priced products could continue to be imported. ${ }^{145}$ The Commission likened the change of political status to a change in ownership of a foreign factory, which has never prevented the Commission from continuing an investigation. ${ }^{146}$ Consequently, the decision by Commerce in Tenex to continue an antidumping duty investigation against six new republics was found legal and upheld for a second time by the Court of International Trade.

\section{The Aftermath: Siginficance and Consequences Of Tenex}

A. Judicial Review of Administrative Proceedings Before Final Antidumping Determination

The first Tenex proceeding in the Court of International Trade created a two-part test to determine whether interim judicial review could be exercised in an antidumping investigation. First, section 1581(i) residual jurisdiction may be invoked only if the legal, not the procedural aspects, of an investigation are being challenged. Second, the possibility that no adverse appealable determination will result from the investigation will compel the court to review Commerce's decision to continue before any final determinations are announced. ${ }^{147}$

Residual jurisdiction under section 1581(i) was granted by Congress in 1980, when the jurisdiction of the Court of International Trade was substantially revised. The legislative history to the proposed Senate bill called it a "broad jurisdictional grant" and stated that the provision "will ensure that in the future these suits are heard on their merits." 148 However, the House of Representatives proposal narrowed residual jurisdiction to apply only when section $1516 \mathrm{a}$ of the Tariff Act does not provide judicial review. ${ }^{149}$ The House version was enacted, and consequently the courts have been willing to invoke residual jurisdiction

145. Id.

146. Tenex $I I, 802$ F. Supp. 473 n.8.

147. See generally supra notes 55-91 and accompanying text.

148. Andrew P. Vance, The Unrealized Jurisdiction of 28 U.S.C. $\$ 1581$ (i): A View from the Plaintiff's Bar, 58 St. JoHn's L. REv. 793, 798 (1984) (quoting S. ReP. No. 466, 96th Cong., 1 st Sess. 3 (1979)).

149. Id. at 801-02 (citing Customs Courts Act of 1980: Hearings on H.R. 6394 Before the Subcomm. on Monopolies and Commercial Law of the House Comm. on the Judiciary, 96th Cong., 1st Sess. 1 (1980)). 
sparingly. ${ }^{150}$ The argument has been made that courts should utilize residual jurisdiction more often because they are "looked to as the bulwark of the citizen's defense against unchecked and unbridled government action." 151 The decision by the court in Tenex to exercise residual jurisdiction would seem to be a step toward controlling arbitrary government action through a more broad interpretation of section 1581(i).

\section{B. Continuation of Antidumping Proceedings After Dissolution of Country} Originally Named in Investigation

In determining that the Antidumping Act does not compel discontinuation of an antidumping proceeding when the country named in the petition subsequently dissolves, the court came to a logical conclusion. The Commission was confronted with a unique and complicated situation when the U.S.S.R. dissolved mid-investigation. However, the decision to continue was reasonable and fair to all parties involved, because it ensured that more information would be gathered before antidumping duties were imposed, and at the same time continued to protect the domestic uranium industry from unfair competition. Deference by the court to an agency administering a body of law is a well-established rule and the court was correct in relying on it. ${ }^{152}$ Further, because of the number of interested parties, the amount of uranium being imported, and the potential consequences of a negative dumping determination on the domestic uranium industry, neither Commerce nor the courts should be forced to prematurely end an investigation. ${ }^{153}$

The purpose of antidumping laws is to protect domestic industries from unfair competition, but the law only goes as far as restoring prices of imported products to the same level as the domestic prices. Although it does not afford monetary damages to the injured domestic producer, this remedy ensures that a foreign entity will not inflate prices after the domestic industry has been eliminated by unfair competition. Pur-

150. See United States v. Uniroyal, Inc., 687 F.2d 467 (C.C.P.A. 1982) (holding that jurisdiction under $\$ 1581(\mathrm{i})$ is in addition to $\$ 1581(\mathrm{a})-(\mathrm{h})$ and should not be used to bypass administrative review) and Lowa, Ltd. v. United States, 561 F. Supp. 441 (Ct. Int'l Trade 1983) (holding that invocation of $\$ 1581$ (i) was invalid because even if the issue was one of legality, the decision should be by the administrative agency).

151. Vance, supra note 148 , at 813 .

152. See generally supra notes $129-41$ and accompanying text.

153. See supra note 94 and accompanying text. 
suant to current American trade policy reflected in the Antidumping Act, the court was correct in allowing Commerce to continue its antidumping investigation against the six former Soviet republics.

\section{Negotiation of Suspension Agreement as Alternative to Antidumping Duties}

The Tenex case continued to create unique controversies even after the two court decisions. In August, 1992, prior to the second court determination, the United States and Russia began discussing an agreement which would suspend imposition of antidumping duties. ${ }^{154}$ If Russia successfully settled with the United States, the other investigated republics (Republics) would join the agreement. ${ }^{155}$ The Antidumping Act provides for suspension agreements in section $1673 \mathrm{c}$ as a substitute to assessment of antidumping duties. ${ }^{156}$ An antidumping investigation will be suspended only if the agreement is found to be in the public interest and it can be monitored effectively. ${ }^{157}$ Three factors which may be considered in determining public interest include (1) adverse impact on consumers, (2) "international economic interests of the United States," and (3) "relative impact on the competitiveness of the domestic industry." 158

Divergent interests of the two governments almost prevented Russia from signing the agreement, but the executive branch of the United States strongly desired a settlement for political reasons. ${ }^{159}$ Commerce

154. Wilson Dizard III and Michael Knapik, U.S., Russian Representatives Discuss Ways of Settling Uranium Antidumping Case, 17 Nuglear Fuel. No. 18, at 1 (August 31, 1992).

155. Id.

156. 19 U.S.C. $\$ 1673 \mathrm{c}$.

157. Id. The relevant portion of the section provides:

[T] he administering authority [ITA] may not terminate an investigation ... by accepting an understanding or other kind of agreement to limit the volume of imports into the United States of the merchandise that is subject to the investigation unless the administering authority is satisfied that termination on the basis of that agreement is in the public interest.

Id. $\$ 1673 \mathrm{~d}(\mathrm{a})(2)(\mathrm{A})$.

158. 19 U.S.C. $\ 1673 \mathrm{c}(\mathrm{a})(2)(\mathrm{B})$. Although the statute states that these factors apply to termination by petition under subsection (a), public interest is undefined for suspension agreements in subsections (b) and (c). The Commission is not compelled to consider these factors in deciding to approve suspension agreements, but they serve as helpful guidelines.

159. Michael Knapik and Wilson Dizard III, Differences Between Russia, U.S. May Imperil Final Agreement in Uranium Dumping Case, 17 NuglearFuel No. 20, at 1 (September 28, 1992). 
wanted an import quota based on prices; if uranium prices from the former Soviet republics rose above $\$ 13$ per pound, it would be allowed to export certain amounts of uranium. ${ }^{160} \mathrm{~A}$ quota table ${ }^{161}$ would allow for increased volume as the price per pound increased, and any price above $\$ 21$ per pound would allow unlimited amounts for all republics but Russia. Russia argued that a quota based on a percentage of domestic nuclear reactor requirements would be fairer. ${ }^{162}$

Frank Fahrenkopf, attorney for Tenex and Nuexco, argued that an antidumping order would fail to protect the domestic industry and "sour relations with the newly independent countries that the U[nited] S[tates] government has said it wants to help." 163 Other speculations followed regarding the effects of suspension agreements. For example, restrictions on foreign uranium sales in the United States were predicted to lead to the loss of American uranium sales in other countries because the Republics would presumably sell to the foreign countries. ${ }^{164}$ Also, it was claimed that price restrictions on the Republics will encourage other low-cost, unrestricted producers to undercut American prices. In effect, the dumping problem would merely shift from one country to another. ${ }^{165}$

Commerce's antidumping investigation was eventually suspended on October 26, 1993, following the signing of quantitative restraint agreements between the United States and all six republics. ${ }^{166}$ The agreements were found to satisfactorily prevent "suppression or undercutting of price levels" by foreign imports, but would be subject to periodic administrative review by Commerce. ${ }^{167}$ Agreements which

160. Id.

161. Id. at 6-7. The editor of NuClEARFuEl noted that the "specific price-quota levels appearing in the Agreement" "were not available, but gave an example of what the table may look like. Id.

162. Id. at 1 .

163. Id. at 3 .

164. Id. at 4 .

165. Michael Knapik, Miners Will Oppose Uranium Agreements Unless all Five CIS Republics Sign, 17 NuclearFuel No. 21 at 20 (October 21, 1992).

166. Uranium From Kazakhstan, Kyrgyzstan, Russia, Tajikistan, Ukraine, and Uzbekistan, 57 Fed. Reg. 48,527 (Dep't Comm. 1992) (suspension of investigations). See also Commerce Enters Suspension Agreements with Former U.S.S.R. Republics on Uranium, INTERnational Trade Reporter (October 21, 1992).

167. Antidumping, Uranium from Kazakhstan, Kyrgyzstan, Russia, Tajikistan, Ukraine, and Uzbekistan, 57 Fed. Reg. 49,220 (Dep't Comm. 1992) (detailed notice of suspension and amendment of preliminary determination). The Antidumping Act requires that an agreement which revises prices is acceptable only if it serves to "eliminate completely the injurious effect of exports to the United States of that merchandise" and the suppression or undercutting of domestic prices will be prevented. 19 U.S.C. $\$ 1673 \mathrm{c}$ (c). 
control prices are encouraged under the Antidumping Act, especially when "extraordinary circumstances" exist. Extraordinary circumstances, according to the Antidumping Act, exist when suspension would be more beneficial to the domestic industry and the investigation is complex. ${ }^{168}$ The term "complex" is defined as a large number of transactions, novel issues, or large number of firms involved. ${ }^{169}$ Congress probably did not provide for suspension agreements in the Antidumping Act merely to have that provision ignored.

Although Commerce never expressly stated how the suspension agreement would benefit the domestic industry, the circumstances in Tenex clearly were complex enough to be considered "extraordinary." In fact, the deadline for preliminary determinations was extended because the ITA considered the case extraordinarily complicated. ${ }^{170}$ The dissolution of a country being investigated has never occurred in seventy years of antidumping investigation, thus presenting a novel issue to Commerce. ${ }^{171}$ The parties in Tenex included six independent countries and their respective uranium-producing companies, an exporter, an importer, at least thirteen domestic companies, and a labor union. ${ }^{172}$ The investigation covered imports of uranium from January 1990 to August 1991, which involved a large number of transactions. ${ }^{173} \mathrm{Com}-$ merce probably found the case extraordinary enough to suspend an investigation for the same reasons it concluded the case to be complicated enough for postponement.

According to Michael Sandler, an authority on international trade, voluntary restraint agreements provide "diplomatic flexibility in serious trade disputes" and allow the United States to avoid "many of the political and international repercussions of unilaterally imposed remedies." 174 In the interest of preserving positive foreign relations with fledgling democratic countries, it may have benefitted the government to initiate negotiations for an agreement in January 1992, immediately following the dissolution of the U.S.S.R.

168. Id. The circumstances require for allowing a suspension agreement are quite similar to $\$ 1673 \mathrm{~b}(\mathrm{c})$, which allows extension of the preliminary investigation period in cases which are "extraordinarily complicated." Id. $\$ 1673 \mathrm{~b}(\mathrm{c})$.

169. Id.

170. See supra notes $48-50$ and accompanying text.

171. Postponement, supra note 48.

172. Initiation, supra note 39

173. Id.

174. Sandler, supra note 9 , at 790. 


\section{Conclusion}

The decision by Commerce to continue its antidumping duty investigation after the U.S.S.R. divided into twelve independent republics was correct under the circumstances. However, international trade has evolved significantly since the first Antidumping Act was enacted in 1921. An increasingly global market means that it is critical for the United States to maintain and improve trade relations with other countries. Indeed, President Clinton's current trade policy has been reported to have an "emphasis on competitiveness, reciprocity, [and] industrial policy," which reflects the need for "reform at home." 175 Opportunities to develop positive relationships increase as the number of independent countries increase. The difficult issues raised in Tenex should not serve to discourage newly independent countries from openly trading with United States companies. Instead, the aftermath of Tenex should serve to open the door to an increasing number of voluntary restraint agreements in lieu of antidumping duties.

Marion G. Schnerre*

175. See International Trade: Clinton Emphasis on Competitiveness May Sharpen Trade Dialogue, Dobbins Says, Daily Report For Executives: Regulation, Economics and LAw (March 5, 1993), available in WESTLAW, BNA-ATR database, 1993 DER 42 d5.

* J.D. Candidate, 1995, Indiana University School of Law-Indianapolis. 
